\title{
IETS OVER PHASMIDAE-EIEREN
}

\author{
DOOR \\ R. A. POLAK \\ Beheerder van het Insectarium van het Kon. Zoöl. Gen. „Natura Artis Magistra” \\ te Amsterdam \\ Met één figuur
}

In het insectarium van „Natura Artis Magistra” kweek ik reeds gedurende meerdere tientallen jaren achtereen zes soorten Phasmidae. Deze zijn Eurycnema herculeana BR., Dixippus morosus Br., Phyllium pulchrifolium SERv., Phyllium siccifolium L., Diapheromera femorata HARR. en Bacillus rossii F. Met uitzondering van Phyllium siccifolium, welke soort ik slechts enkele malen gekweekt heb ${ }^{1}$ ), zijn de overige vijf permanent in het insectarium vertegenwoordigd.

Opmerkelijk is, dat uit de geimporteerde eieren van Eurycnema herculeana sieeds uitsluitend wijfjes komen. De volgende generaties van de te Amsterdam gekweekte exemplaren van deze soort bestaan uit mannetjes en wijfjes, en wel van beide geslachten ongeveer hetzelfde aantal. In Nederl. Oost-Indië schijnen de mannetjes zeldzaam te zijn. Entomologen, die geruimen tijd in Indië hadden gewerkt, zagen in het insectarium te Amsterdam voor het eerst de mannetjes van deze soort.

Verder schijnt het mij opmerkelijk, dat eieren van nauwverwante soorten in habitus zeer veel van elkaar verschillen (Phyllium pulchrifolium en Phyllium siccifolium), terwijl die van veel minder verwante vormen een belangrijke convergentie in den vorm vertoonen (niet in de grootte: Dixippus morosus en Eurycnema herculeana).

De eieren van Eurycnema herculeana, Dixippus morosus en Phyllium pulchrifolium dragen vóór de micropyle een uitsteeksel, dat bij het uitkomen der larven wordt afgeworpen. Phyllium siccifolium draagt rondom die plaais een krans van gebaarde tandjes.

Genoemd uitsteeksel, hetwelk bij Bacillus rossii en Diapheromera femorata ontbreekt, schijnt van belang te zijn voor de verspreiding der soort; op welke

1) Van deze soort ontving ik van Java eenige malen de eieren, waaruit ik steeds de imagines heb kunnen kweeken. Doch uit de in het insectarium afgezette eieren kreeg ik nimmer larven, ofschoon ik meermalen cupula heb waargenomen. 
wijze het daarbij betrokken is zal uit het onderstaande blijken. Ik grond mijn meening op de volgende waarnemingen:

De wijfjes van alle door mij gekweekte Phasmidae zijn òf apteer, ò ze dragen vleugels, waarmede zij niet tct vliegen in staat zijn en welke hoogstens als valscherm kunnen dienen. $Z_{i j}$ kunnen zich dus uitsluitend loopend verplaatsen, doch een zoodanige verplaatsing gaat, zooals begrijpelijk. is, niet over grocite afstanden. De wijfjes van deze Phasmidae dragen er dus practisch niet toe bij, het verspreidingsgebied van hun soort te vergrooten. Dit moet dus op andere wijze plaats vinden.

$\mathrm{Nu}$ blijkt, dat de jonge larven van die soorten, aan welker eieren het uitsteeksel ontbreekt, zeer licht en bewegelijk zijn, zoodat zij gemakkelijk door. den wind worden weggewaaid ${ }^{1}$ ). Bovendien hebben ze de neiging naar boven te klimmen. Vooral de larven van Phyllium siccifolium vertoonen dit verschijnsel in sterke mate; ze zijn zeer vlug ter been, zoodat er met de uiterste zorg voor gewaakt moet worden, dat ze niet uit het insectarium ontsnappen. Zijn ze eenmaal aan het eten, dan worden ze rustiger. Deze soort wordt dus hoogstwaarschijnlijk door den wind verspreid in het stadium van jonge larven.

Teneinde het tijdroovende kweeken van Bacillus rossii te vergemakkelijken breng ik in den voorzomer de jonge larven in een rozenperk van "Artis" en zaai daar tevens de eieren uit. In het late najaar verzamel ik de ongeveer halfwassen larven. Steeds vind ik deze dan eveneens in andere perken dan in die, waarin ik de eieren en jonge larven had gebracht.

Het uitsteeksel aan de eieren van Phasmidae-soorten, wier larven niet door den wind verspreid worden, schijnt nu voor de verspreiding van deze soorten van beteekenis te zijn. Het blijkt nl. een buitengewone lekkernij voor op den grond levende insecten te zijn. De kakkerlakken in het insectarium zijn er dol op. Ik heb eenige eieren van Eurycnema herculeana met stukjes banaan in een glas gelegd en er larven en imagines van Periplaneta americana L. bijgezet. De eieren werden van hun aanhangsel ontdaan, terwijl de stukjes banaan ternauwernood aangevreten werden.

Wij zorgen er steeds voor de eieren van Eurycnema herculeana zoo spoedig mogelijk, nadat zij zijn afgezet, uit het insectarium te verwijderen om te voorkomen, dat zij door de kakkerlakken aangevreten worden. Desondanks worden de meeste eieren door kakkerlakken geschonden, aangezien het niet mogelijk is, het insectarium altijd, ook des nachts, te bewaken; het heeft vrij groote openingen, voor het indruppelen en afvloeien van water, hetgeen noodig is, om den „wandelende takken" een vochtige omgeving te verschaffen. Zelfs des daags moeten wij op onze hoede zijn om te voorkomen, dat de eieren door kakkerlakken worden afgeknaagd. Wel komen uit de door kakkerlakken aangevreten eieren even levenskrachtige larven als uit de intact geblevene, maar voor ruildoeleinden zijn de laatste toch meer gewenscht.

1) Zie verder mijn medudeeling gedaan op de wintervergadering van de Nederlandsche Entomologische Vereeniging in 1935. 
Het schịnt mij toe, dat het aanhangsel der eieren niet alleen een lekkernij is voor kakkerlakken; maar ook, dat het een stimulans bevat, dat ze in een soort opwinding brengt en ze aanzet tot loopen. Ik heb meermalen gezien, dat kakkerlakken bezig waren de eieren over den bodem van het insectarium te versleepen, terwijl toch ander voedsel gewoonlijk ter plaatse verorberd wordt.

Eieren, die ik in een kunstnest, waarin een kolonie van Formica sanguinea LATR, met Formica fusca LATR., bracht, werden spoedig door de mieren over vrij grooten afstand versleept en van hun aanhangsel ontdaan, zooals mieren

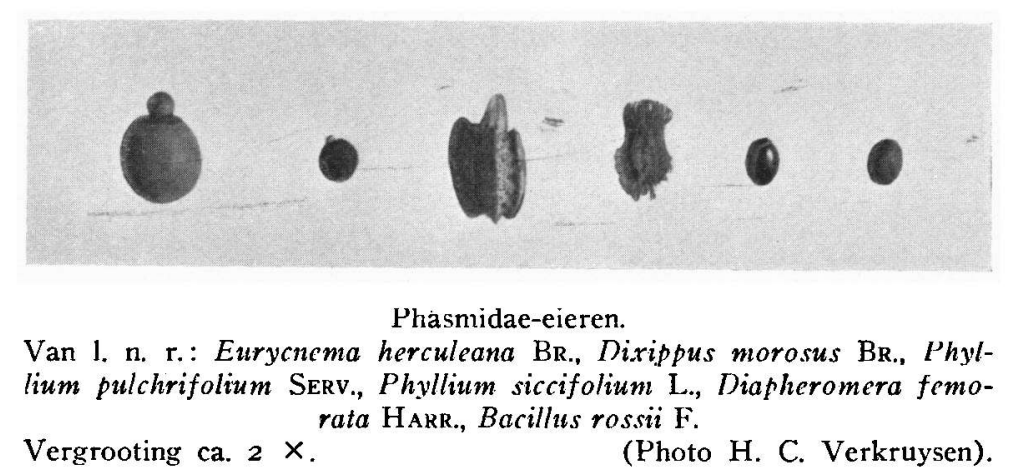

in het algemeen gewoon zijn met haar voedsel te doen. Gaarne zal ik hen, die de aanhangsels van de Phasmidae-eieren chemisch wenschen te onderzoeken, van materiaal voorzien. Gewoonlijk heb ik een vrij groot aantal eieren in voorraad. Verder zullen zendingen van Phasmidae-eieren uit de tropen voor het Insectarium van „Artis” te Amsterdam in grooten dank worden ontvangen.

Tenslotte merk ik nog op, dat sommige Phasmidae hun eieren wegspuiten en daarbij een slingerende beweging met het abdomen maken. Vooral Eurycnema herculeana vertoont dit verschijnsel in sterke mate. Natuurlijk draagt dit ook eenigszins tot de verspreiding bij.

De conclusie, welke ik uit het bovenstaande meen te mogen trekken is, dat verschillende Phasmidae worden verspreid door middel van op den grond levende insecten, die, aangelokt door het eetbare aanhangsel, op de eieren afkomen, het aanhangsel afvreten en ondertusschen de eieren versleepen. 